\title{
ONLINE PEER ASSESSMENT IN NURTURING STUDENTS' WRITING SKILL
}

Mahardhika Pradana1, Maya Rahmawati2

Universitas Singaperbangsa Karawang, Indonesia

mahardana96@gmail.com

maya.rahmawati@fkip.unsika.ac.id

\begin{abstract}
This study aims to investigate the process of online peer assessment implementation in a writing activity and to find out the students' responses toward the implementation of online peer assessment in learning writing skills. This research uses a qualitative approach and case study as the research design. The data were collected with the triangulation data by observation, interview, and documentation. Observation checklist, in-depth interview, and documentation used as data retrieval instruments. The subjects of this study are the English teacher and students of class XI TKJ 1 at SMKN 1 Rawamerta that consists of thirty-two male students. The result of this study shows that the implementation of peer assessment in writing skills is very effective to help the students in learning writing and evaluating learning process through WhatsApp. Before the implementation of peer assessment, the students were not able to recognize their mistakes in detail, they could only find out about the numerical score, and did not know about how to assess. Based on the result obtained, it is concluded that teaching writing to the students' responses toward the use of peer assessment was positive. It can be seen from the attitude and enthusiasm.

Keywords: Peer Assessment, Writing Skill.
\end{abstract}

\section{INTRODUCTION}

Writing skill is emphasized on refining by students themselves. It can be traced from pre-observation data that the students are used to write English through their capacity. Therefore, they do not have proper suggestions on how to refine their writing. Empirical evidence reported by Grahari \& Fahronia (2015). In Vocational High school, writing skill is one of the skills of English taught at formal schools.

Based on the curriculum of Vocational High School in the standard of competency, one of the objectives of the English subject is that the students can develop their competency of communication in oral and written form to achieve an informational literacy level (Diknas, 2006: 308). The objective of the English subject above means that the students are expected to communicate either in writing skills or in writing.

However, based on the preliminary study conducted at the second-grade students of SMKN 1 Rawamerta, some facts have been found. Firstly, the teachers seem to have failed in engaging students to get involving actively and seriously in the teaching and learning process and the teachers seem not to encourage students' motivation and learning engagement in the classroom so that students' engagement in the in-class writing activities is low (Iksan \& Dirham, 2018). Secondly, teachers were not to build a good classroom interaction through 
the teaching and learning process (Kaso et al., 2021). Thirdly, English is not the mother tongue to communicate every day, students have limited access to learning facility such as unable to buy handbooks, dictionaries, CDs or other supporting media. This is due to the low income of the family.

In addition, the researcher found that students were lacking the capability to write good English. For instance, the content was irrelevant to the topic, the variety of ideas or arguments and lacking accurate details. In terms of the organizational of the written text it is also not in line with the structure of the organization of the written texts. Thus, most of the students' written works were lacking creativity and were very difficult to understand.

Moreover, since the students also lack vocabulary, it has also had some mistakes in choosing the right words or idioms in the students' written works (Wiraldi, Jufriadi, 2020). Finally, most of the students' writing problems were in word choice, spelling, punctuation, capitalization and coherency. In addition, limited time is one of the problems involving teachers and students. Enough material is not balanced with the time allotted, so this is a reason for ineffective learning. The phenomenon of "Social Media boom" can be utilized to overcome problems in the world of education (Tsauri, 2010), especially in terms of peer assessment. Peer assessment activities conducted by students online by utilizing the WhatsApp network can be a bridge to the problem of time needs that usually exceed the time allocation that has been provided when conducting conventional peer assessment.

In addition, the use of the WhatsApp network in the use of online peer assessment will save costs because each student can have a free WhatsApp account through their phone number, all rubrics and student work in the form of narrative text do not need to be printed, simply uploaded via WhatsApp notes, whereas for assessments will be sent via WhatsApp message to maintain confidentiality. In addition to saving costs, this will also make archiving easier. Implementing online peer assessment in teaching writing provides many benefits. The benefits are a focus on the development of student's enthusiasm and help students on learning writing by peer feedback on WhatsApp network. Students would involve on the process and encourage to take part ownership of this process provides more relevant feedback to students as it was generated by their peers.

From the explanations above, there are some reasons why the researcher chose this topic. The issues are interesting to help students with a writing activity. The peer assessment technique requires students to learn how to translate and write text in English, especially narrative text then feedback given by students to each other. The material used is a student handbook about narrative text and each group should translate and will upload by groups on WhatsApp network. Finally, students analyze, giving comment or feedback by peer.

\section{METHODS}

In this research, the researcher uses a qualitative approach to achieve the objective of the research. Heigham and Croker (2009:5) stated that qualitative research entails primarily textual data and examines it using interpretive analysis. This approach is used since the researcher solely describes the learning process taking place in the classroom.

For the research design, the researcher uses a case study method that is research on involvement of the documented history and comprehensive analysis of a situation 
concerning subjects such as industries, organizations, and markets. The distinguishing factor of the case-study methodology is that it aims to bring out unique characteristics and interesting differences in the situation under observation.

The subject of this research has been limited to the teacher and the XI-TKJ 1 class of the eleventh-grade students in SMKN 1 Rawamerta in 2019/2020 academic year. There are many reason for choosing this site: 1) Because the school is still active in the learning process that relate to the English skill via online; 2) The researchers have had a quite connection to the school through distance learning; and 3) The English teacher who have implemented peer assessment in learning process, is a graduate student of UNSIKA which made it easier to cooperate with the teacher in this research.

The data resource that would be analyzed is students of class XI-TKJ 1 that consists of thirty-five students in total which consists of eleven males and twenty-four females. The researcher uses purposive sampling to choosing the students as the resource persons to know students' responses.

Brown (2012) stated that "purpose sampling is removal sample technique data resources with a certain judgment". In this research, the researcher chooses six students and an English teacher. The researcher chooses two students in high achievement, two students in medium achievement and two students in low achievement to know the students' response, and also the researcher chooses this class to research because it has English skill is better than other classes in XI-TKJ 1 and the teacher used to be recommending this class to do this research.

\section{RESULTS}

The results of this research were obtained through online class observation, interview, and documentation in the form of photo or screenshot as the evidence of the research during the online research conducted. On class observation the teacher and researcher used WhatsApp Group chat as alternative learning in the classroom because the situation is not safe due to the pandemic of COVID-19 which force the school to be shut. Thus, researcher used google form for taking the data of interview.

\section{The Procedures of Peer Assessment in Writing Activity}

Based on the data from observation and interview, the process of implementing peer assessment in writing skill had four steps, namely; introduction, preparation, implementation or application and evaluation. The steps can be specified as follows: 
Chart 1. The procedures of online peer assessment in nurturing students ' writing skill

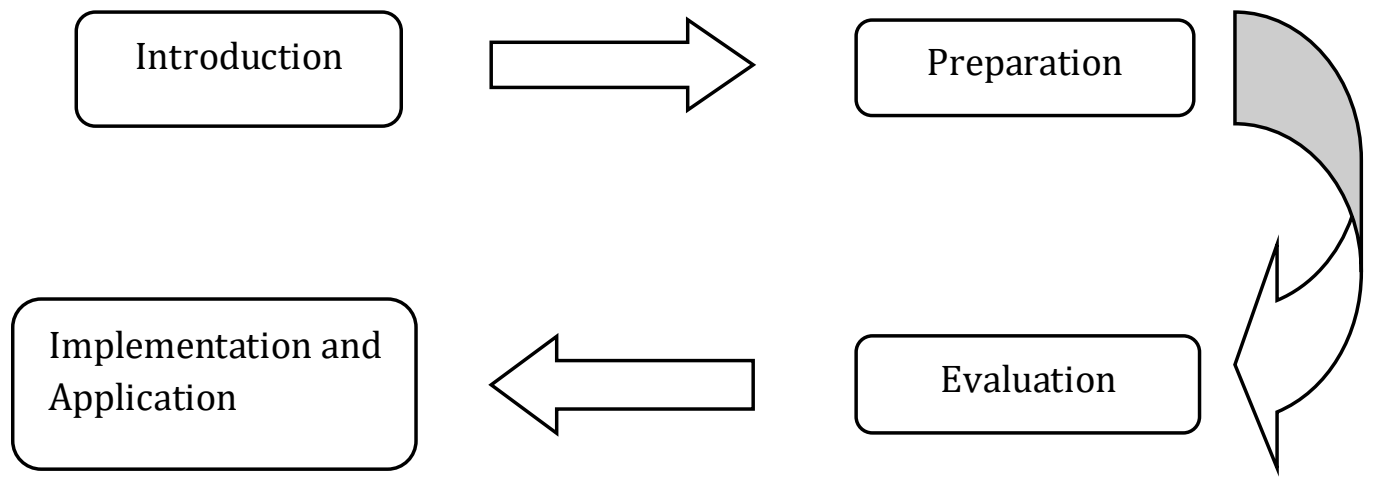

The chart above explains the online peer assessment process in nurturing students' writing skills. This procedure has been applied to class XI TKJ 1 in writing learning, this is elaborated as follow:

The first phase on the introduction the teacher introduced about concept of peer assessment. They are: definition, purpose and benefits of per assessment.

Picture 1. Introducing the observer to the students

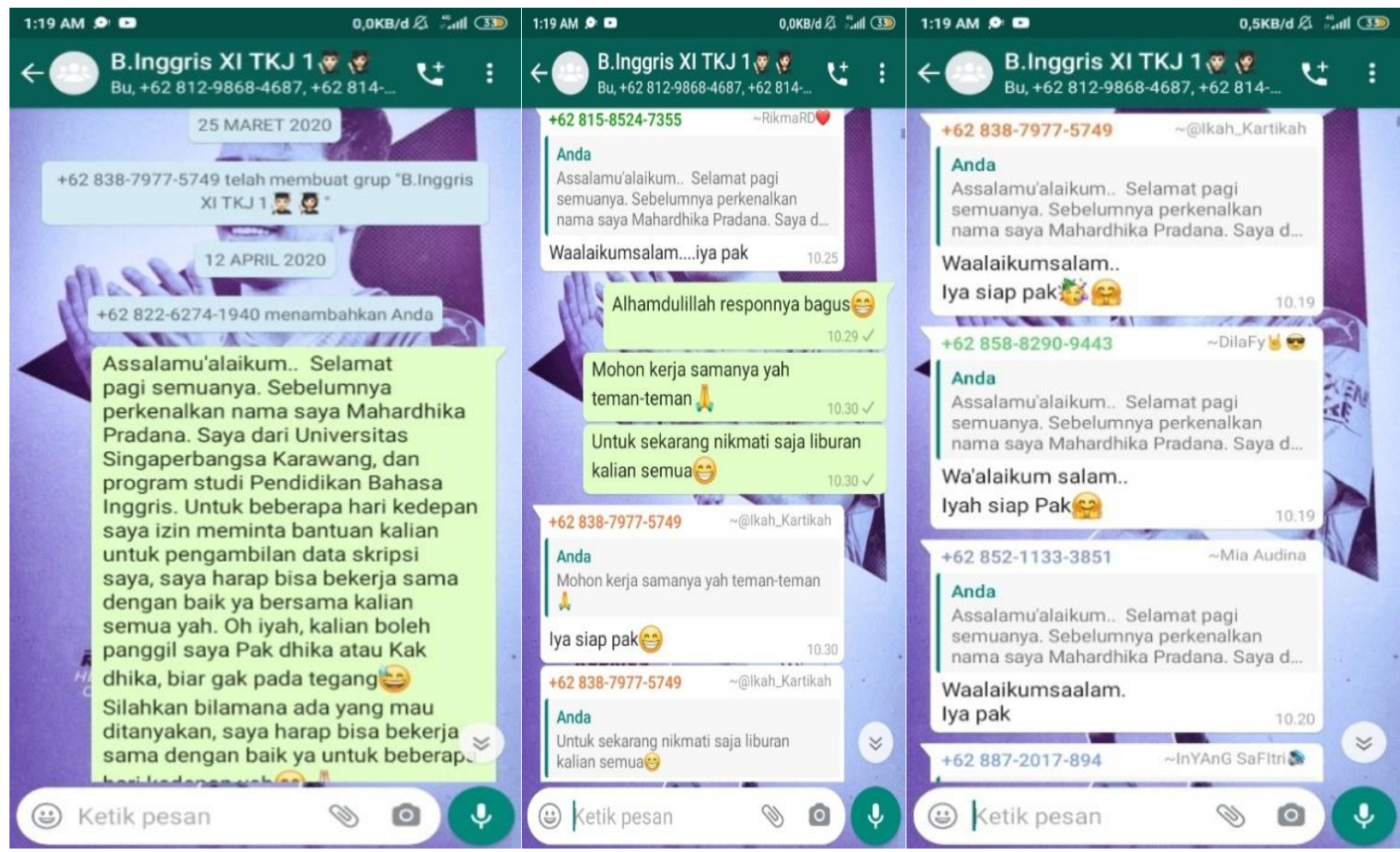



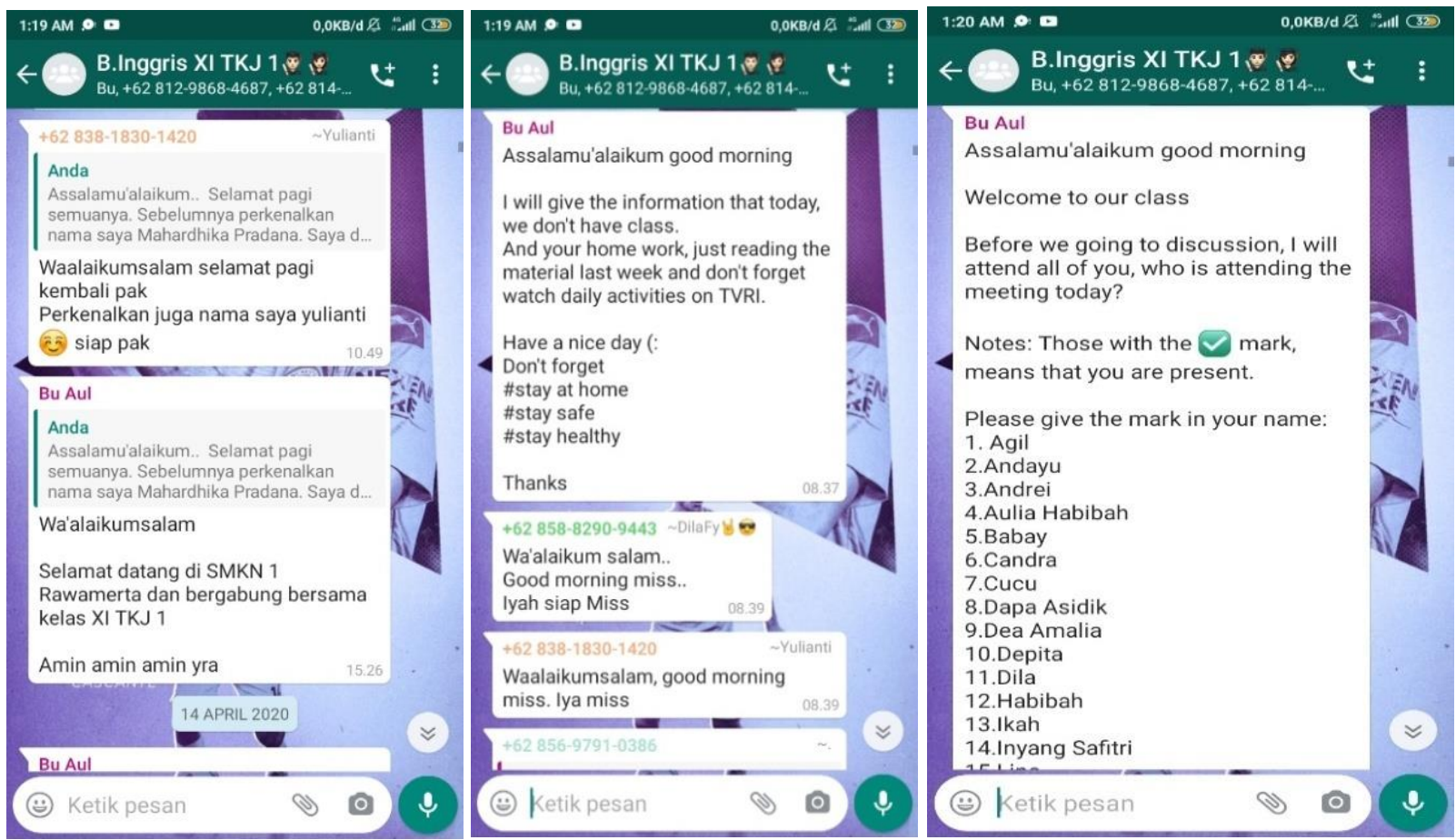

On the picture above explained the teacher and observer's activity in introducing the identity of the observer or the researcher to the students. The purpose is to begin the research of peer assessment with harmony and cooperativeness with all the subject included.

\section{Picture 2. Introducing the concept of peer assessment}
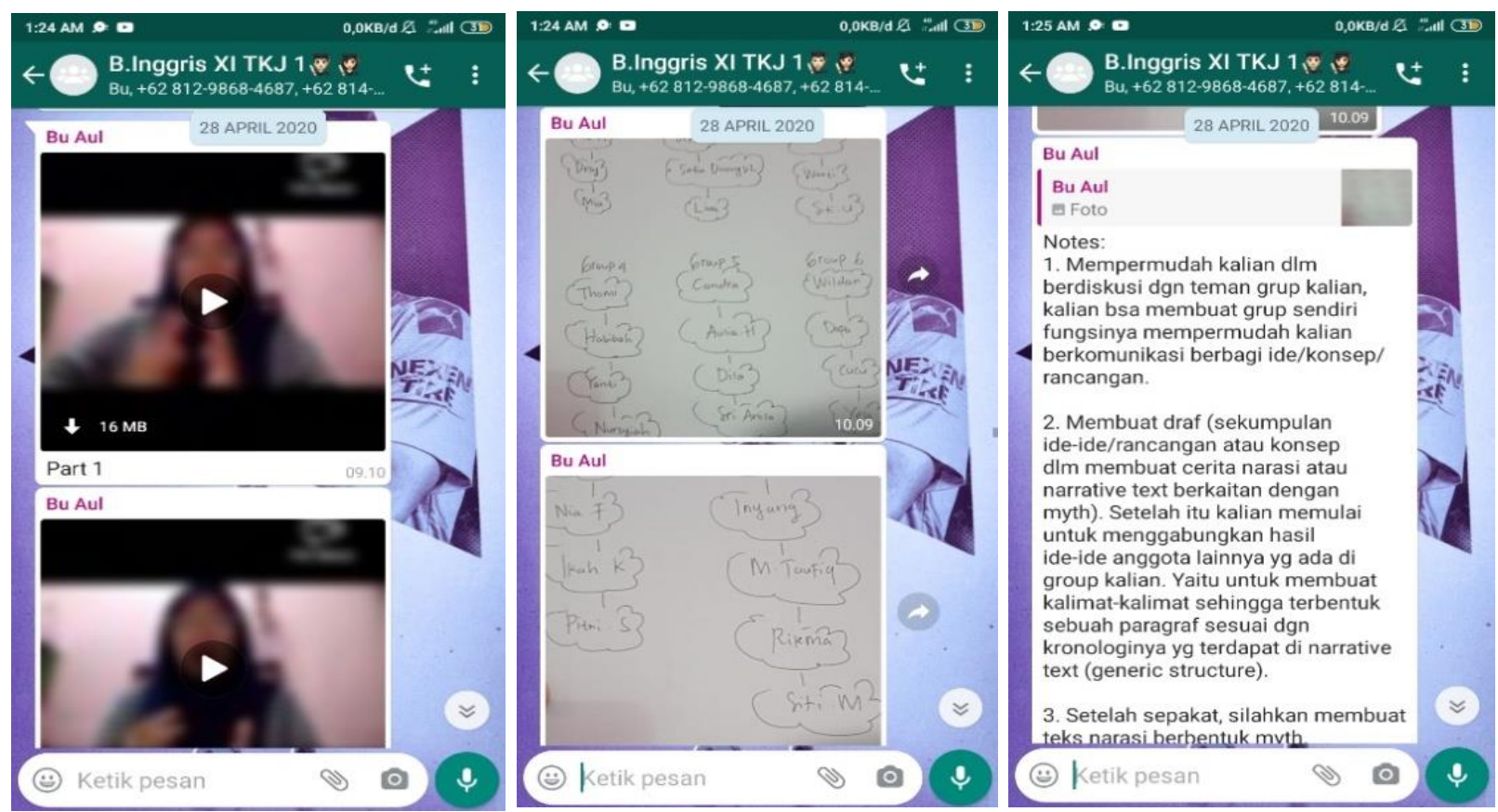

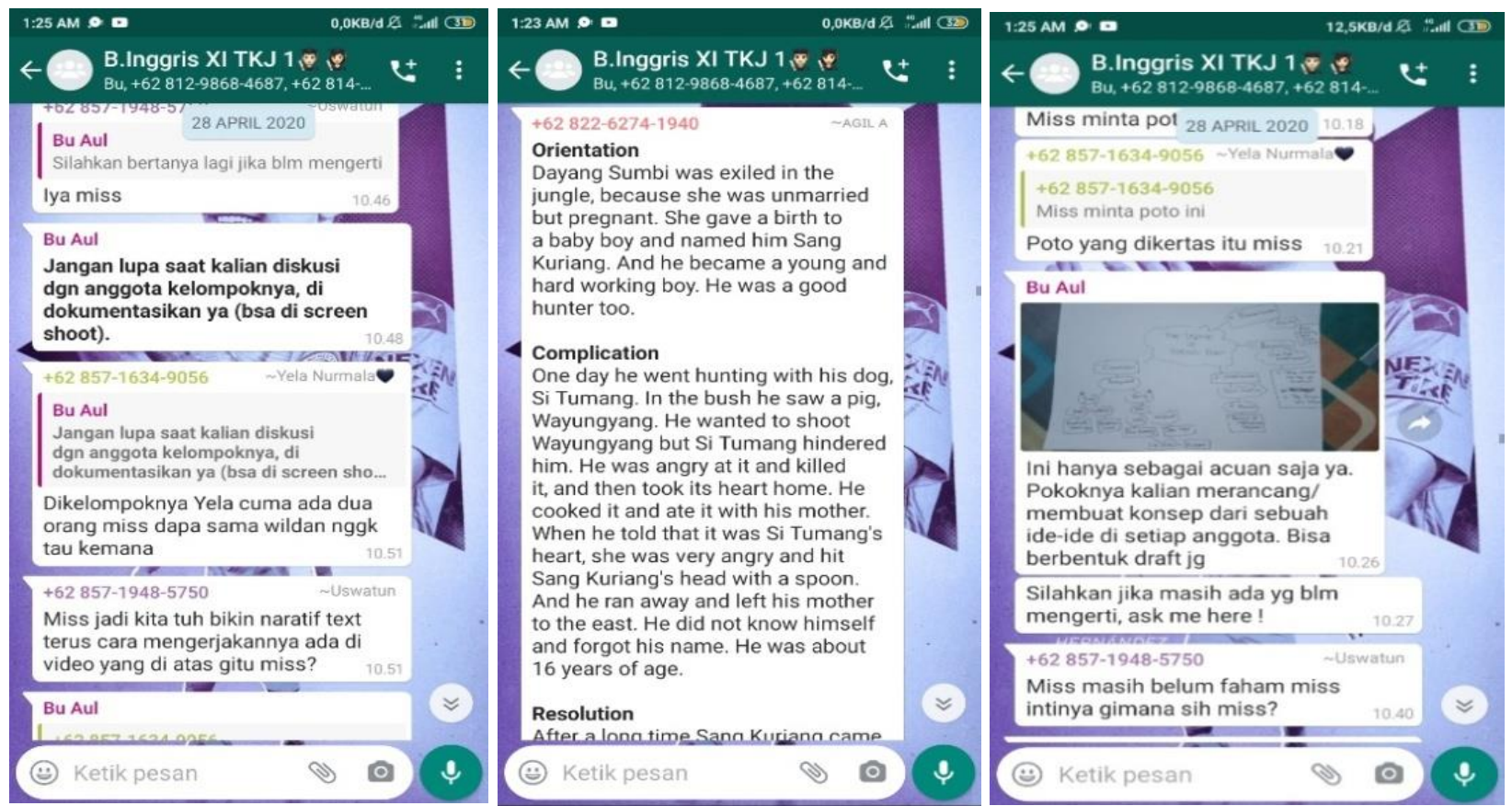

The picture above explained the teacher introduced definition, purpose and benefits of peer assessment. Students must understand about the definition, purpose and benefits of peer assessment before the teacher implemented peer assessment in the writing activity.

The second phase is preparation where the teacher trained the students in one meeting before she implemented online peer assessment in writing activity. In addition, the teacher prepared the learning materials, Students' groups and the last explained rubric of peer assessment.

Picture 3. Explaining the rubric of peer assessment
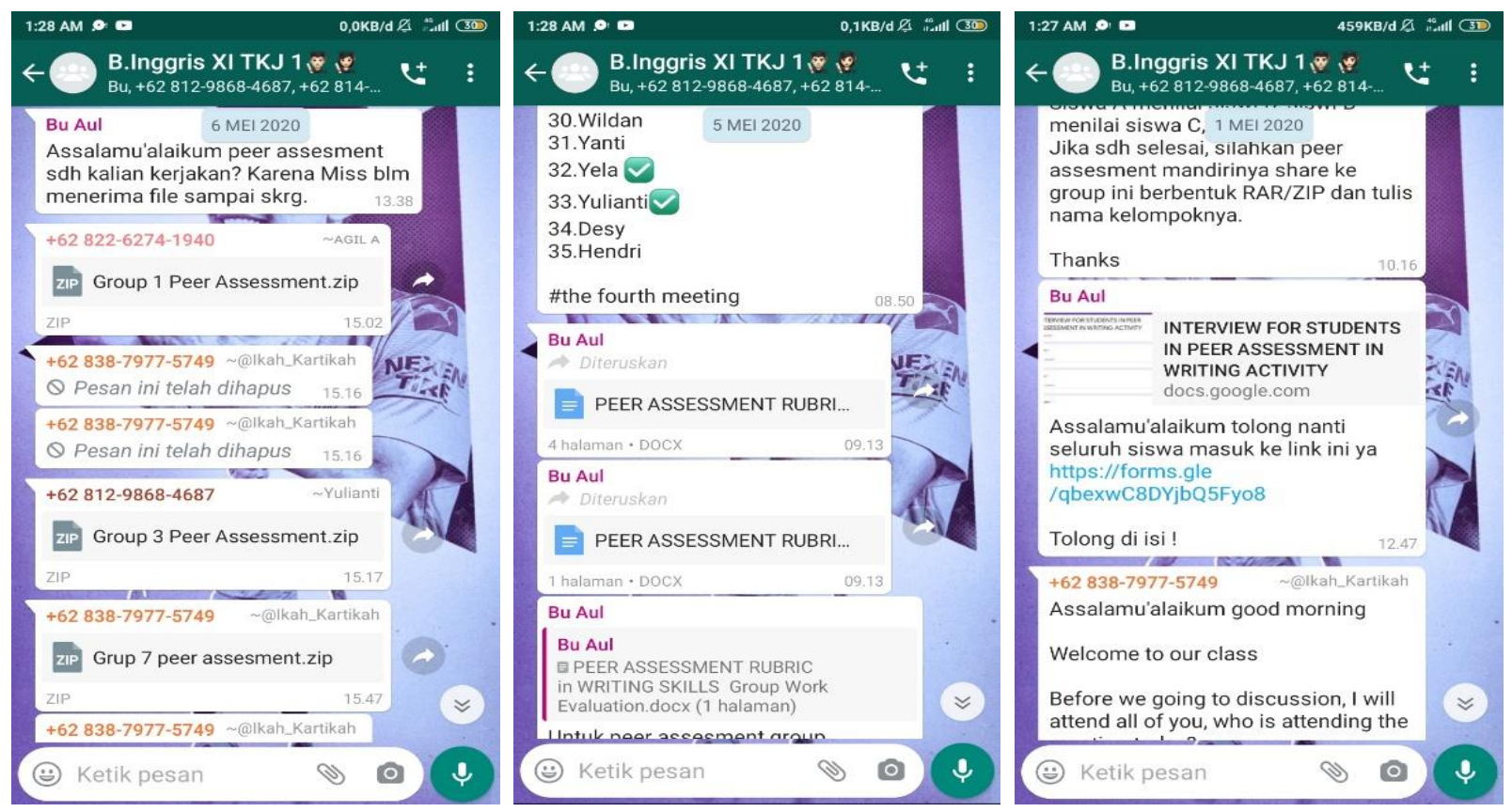

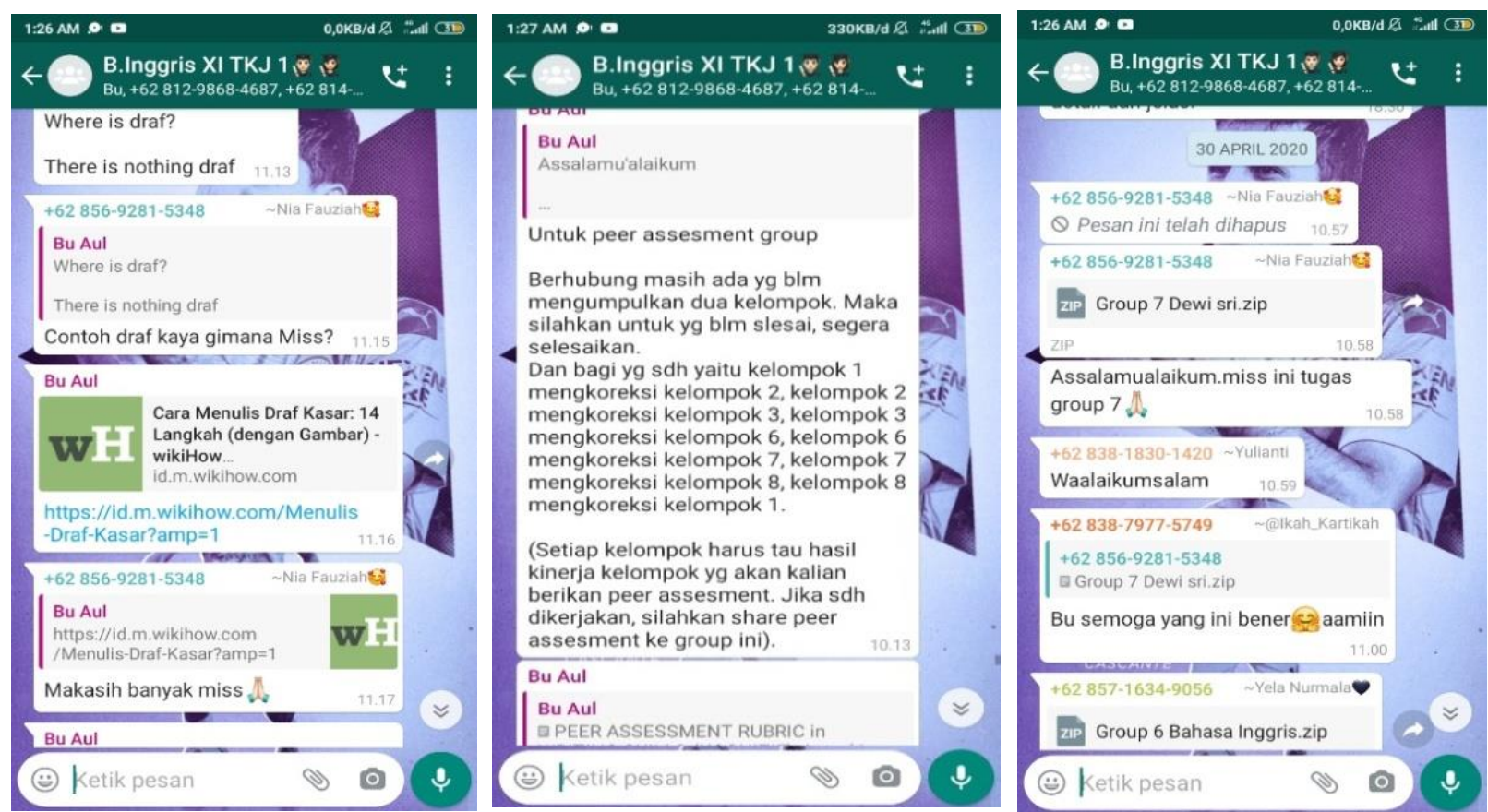

Moreover, the picture above showed the teacher explained the rubric of peer assessment through WhatsApp application. The rubric criteria focused on writing comprehension. This rubric is used to evaluate teaching-learning process in writing activity. Therefore, the students can be focus on giving score by using the criteria of this rubric.

The picture also showed students from each group present the material of this subject by sending some files as the result of their works as a group. It is a conversation by student performance in the online classroom as well as to evaluate their weakness in the subject by asking their teacher or their classmates. Thus, other students must pay attention to assess also to be assessed and give the written comment to evaluate their peer task. The teacher did not focus on the score or result of this rubric, the teacher used this rubric to enhance the students to assess their peer and to evaluate by giving a written comment.

The third phase on implementation of peer assessment is that the students had been assessed and gave a written comment to their peer. 
Picture 4. Writing activity and process of peer assessment by online comment
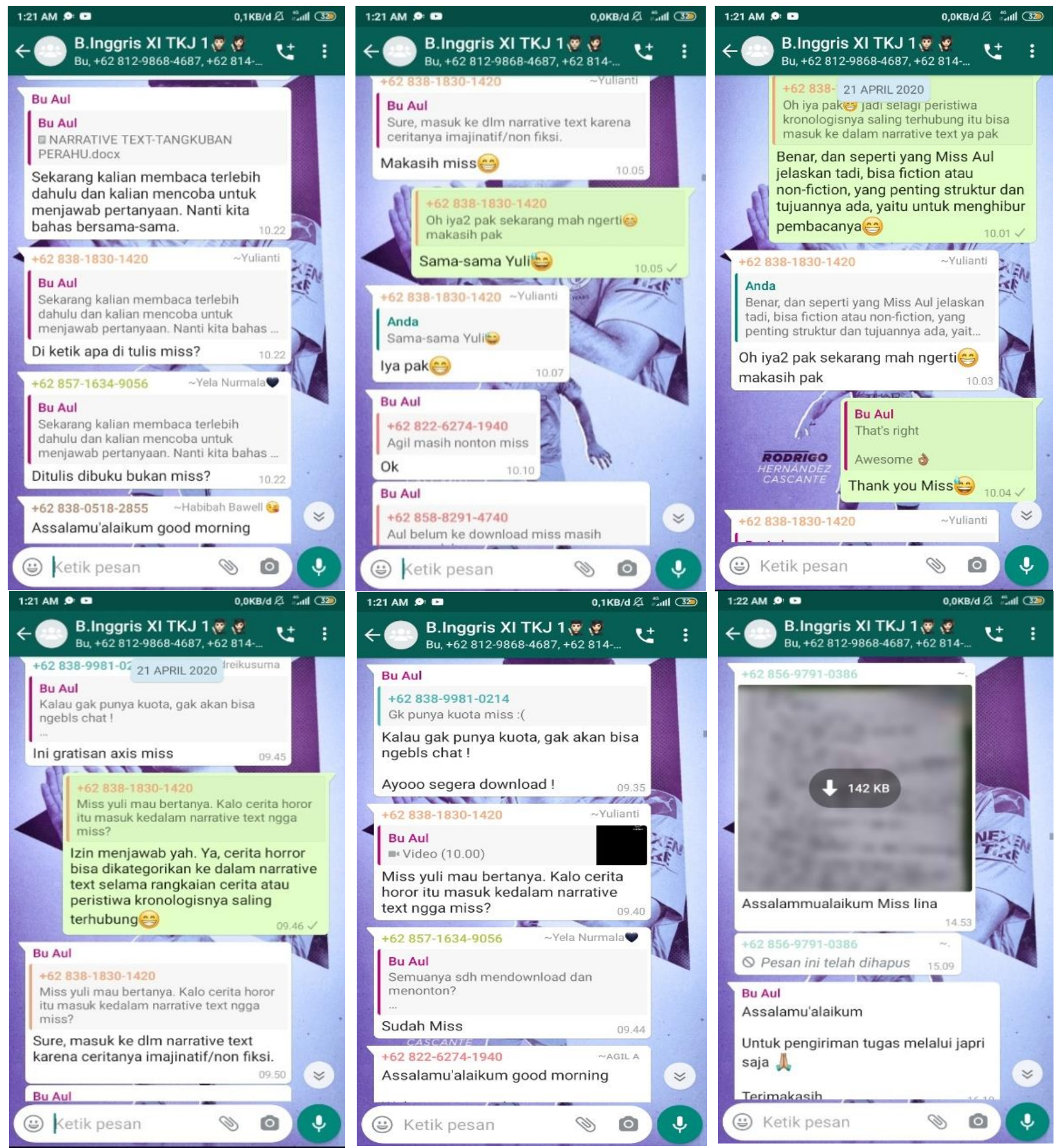

The picture above showed students from each groups send the result of their works of narrative text. It is also form a written conversation by students in the WhatsApp group when the representatives send the task. Thus, other students must pay attention to assessed, assessing, given written comment to evaluation their peer performances and tasks. Students assess their peer using 
the rubric to give the score. The teacher gave the guidance not feedback during teaching-learning using peer assessment in the WhatsApp group (Online classroom).

The fourth phase is evaluation where the teacher gave some result of students' achievement, students' progress and problems after implemented peer assessment. The teacher asked students to written narrative text as a task to find out the students' progress. The teacher gave feedback to the students' evaluation and to solve the problems during implementing peer assessment in online learning.

Thus, the teacher took the rubric to each groups after implementing peer assessment in the classroom and comparing it to understand the students objectively, validity and reliability of the rubric that used by students and the teacher.

\section{Difficulties and Objectives Peer Assessment Implementation in Writing Activity}

Peer assessment is a great technique to be used in the classroom to help students reach their own achievement. Based on datathe observation and interview, this technique was rarely used by English teachers even though it can develop students' involvement in assessing their peers by employing their own knowledge. The lack of understanding and a doubtful feeling about the result of peer assessment implementation are two factors which hampers teachers to use this technique of assessment over the teaching and learning process especially in writing activity.

\section{Students Difficulties of Learning Writing}

Writing is a tool for interacting with other people and productive skills that must be mastered by students in learning languages so that they become good communicators. Based on the data of observation and interview, students found difficulties on learning writing. First, English is not their mother tongue to be used in daily communication which makes them difficult in pronouncing it. Students have limited access to learning facility such as unable to buy handbooks, dictionaries, CDs or other supporting media and limited internet access for online learning. It is caused by the low income of the family.

Third, students were less enthusiastic and less interested on mastering writing so that in students' engagement in in-class writing activities is low. These issues caused them to be unable to perform well in English writing task.

\section{Students Objectivity of Peer Assessment}

Based on the data observation and interview, the objectivity is to find out the student objectively in peer assessment that can be seen from the results of the assessment using in the rubric.

In this study, the teacher used rubric which is in accordance with the skills to be learned, namely writing. There were two types of the rubric used for teachers and students. It was only a difference in gave comments only if rubric for teachers there were only scored and criteria for assessment. But, for students, there were a comment column that student can be written comment for their peers to evaluated learning process especially students' task.

Based on the observation and interview data, at the end of the lesson, the teacher collects rubric ratings from students and compared them with the rubric in the teacher. If the results are not found to be a significant difference, it can be concluded that students have been objective in giving value to their peers. 
Advantages and Disadvantages of Peer Assessment

Based on data the observation and interview, the advantages of peer assessment there are helping students become more independent, responsible and active. Thus, encourage students to critically analyze the work done by others, not just value. Helping students clarify assessment criteria, providing broader feedback. Strengthen the students' collaboration and solidarity because of group values. Last, save time the teacher to evaluation the students and teaching-learning process.

Thus, the disadvantages of peer assessment, there are the students lack the ability to evaluate one another. Students often do not take seriously because they are friends with each other. Some may worry that the students may feel that assessment is a teachers' job, so they may not be serious in assessing their peers.

Others may think that friendships could influence a students' assessment so that they could give a good score to a close friend and a bad score to an enemy. And then from the internet access is also limited and expensive to be bought or acquired by some students in this research.

\section{DISCUSSION}

\section{Implementation of Peer Assessment in Writing Activity}

Based on the data described above can be discussed, the researcher found that the implementation of peer assessment in writing activity. The teacher used this technique to help the students learn writing.

Peer assessment had four steps, there are introduction, preparation, implementation and evaluation. The teacher was conducted at one meeting before the implementation of peer assessment in the classroom for trained students because students must understand about definition, purpose and benefits of peer assessment before the teacher implement peer assessment in a writing activity. This supported by White (2009) in Yunella (2017) about the students must understand concept of peer assessment, he says that for implementation of peer assessment, students must understand the technique of peer assessment which must explain by the teacher.

There are four procedures in implementing peer assessment on writing of conversation expressing suggestion and offer, there are;

\section{Introduction}

The first phase the teacher introduced and given peer assessment concept. The teacher explains about the definition, purpose and benefits of peer assessment before the teacher implement peer assessment in writing activity.

\section{Preparation}

The second phase the teacher trained students before the teacher implement peer assessment in writing activity. It was important steps to helped students used peer assessment. It was appropriate with Edwards (2013) about key successful factor of peer assessment, he say that training is therefore considered to be the key factor in the success of 
peer assessment. Other than that, the teacher prepared materials of study, learning media, groups and the last explained rubric of peer assessment.

\section{Implementation or application}

The third phase the students must be assessed, assessing and gave the written comment in online classroom to their peer. Students assess their peer used the rubric to given score. The teacher gave a guide but not gave feedback during the teaching-learning using peer assessment.

\section{Evaluation}

The fourth phase the teacher gave some result of students' achievement, students' progress and problems after implemented peer assessment. The teacher gave feedback to the students' evaluation and to solve of the problems during implementing peer assessment in the classroom.

It was supported with Okuda and Otsu (2010) in Yunella (2017) about the procedures of peer assessment, they say that set out the procedures for peer assessment first, assess criteria and format of rubric. The teacher may take the rubric from an expert or adapt one based on the type of performance, the skills of the students and the classroom situation. Second, explain the criteria of the rubric to the students. It is a crucial thing to explain the criteria of the rubric to the students. Teacher must give clear explanations about the rubric and on how the students must assess their peer. Third, training the students to applied peer assessment.

Before applying the peer assessment in the classroom, it is better to make a simulation in implementation of peer assessment. Fourth, last but not least, for the procedures of peer assessment is that each classmate fills out a rubric sheet for the performance of each of their peers. The researcher also found that the teacher implementation peer assessment as formative assessment. The teacher implemented peer assessment to the students in high achievement, medium achievement and low achievement. It like an alternative assessment to evaluated the learning process on writing activity. It was relevant on previous study by Yunella (2017), she says that Peer assessments are a section of formative assessments. This sort of assessment focuses on the students' desires instead of on the teacher's wants or needs.

The teacher also used peer assessment for designing learning environments on writing activity. Students can be assessed, assessing, commenting their peer by their work and made their judgments reasonably accurate on peer assessments. This supported by Sahin (2008) in Alzaid (2017) about the choice assessment, he stated that peer assessment is one in every of the choice assessment ways, that trained students in teaching to use peer assessment as a tool of analysis and compared it to teacher assessment.

Thus, in this research can be concluded that implementation peer assessment focused on formative assessment to evaluate teaching-learning process not usage peer assessment as summative assessment to evaluate students' skills. Thus, peer assessment focused on gave written comment not gave a score to helped students learn to speak and develop their writing ability. Students engaged in the evaluation of their learning process by written 
comment. Peers comments about the way students delivered the presentation helped them to improve their performance.

It was appropriate with White (2009) in Yunella (2017) about purpose of peer assessment, he stated that the purpose of peer assessment in assessing writing is to improve students' writing skill. By using peer assessment in writing, students are expected to develop their ability in presenting the material. Another previous study by Rimer (2007) in Alzaid (2017) about peer assessment usage, he says that peer assessment is used to enhance learning as an effective way to increase motivation for students by engaging them in the evaluation process which has received attention in recent years from a number of international universities.

This also was relevant with the previous research by Faudi (2017) about effectively peer assessment usage, he says that peer assessment technique was effective implemented in teaching writing. It has significantly increased the students' paragraph writing narrative text. It can be concluded that peer assessment can be applied both in speaking and writing. In addition, Nelson and Schunn (2009) differentiate feedback into cognitive and affective categories. Cognitive feedback targets the content of the work and involves summarizing, specifying and explaining aspects of the work under review.

Affective feedback targets the quality of works and uses affective language to bestow praise ("well written") and criticism ("badly written"), or uses non-verbal expressions, such as facial expressions, gestures and emotional tones. In online learning environments, emoticons are often used for giving affective feedback. Based on Nelson and Schunn (2009), and Tseng and Tsai (2007), comments were first coded as affective comments were further coded as positive (e.g. "very good") or negative (e.g. "badly written").

Peer assessment allows students who are not involving in the writing task to become more experience in listening to spoken English, to engage more deeply with the learning goals and expecting outcomes of the writing course, and to learn from each other. For this research, the researcher uses a specific strategy that were found to be fruitful in enhancing peer interaction during peer review, such as the use of both L1 and L2 (instead of merely L2) (Yu, 2016).

Furthermore, peer assessment is an important part of the move towards more forms of participatory learning. There is a need to apply it in our schools and universities since it is more adaptable to modern developments in the assessment of learning outcomes. This supported by Kollar \& Fisher (2010); Tan \& Keat (2005) in Alzaid (2017) about important of peer assessment technique, they are say that peer assessment is an important element of designing learning environments in order for them to become more participatory among students, which can achieve concepts such as learning between peers, collaborative learning, and problem-solving based learning.

\section{Students Response Towards Peer Assessment Usage in Writing}

Based on data the observation and interview, the researcher found that generated students' responses about peer assessment. They were agreed that peer assessment is very effective technique way to the helped student in learning writing and evaluating learning process, to find and solve their problem on writing learning process, implemented peer 
assessment was not difficult, can be made a good relationship between their peers by their group work, can be active participant and critically analyze, can made student get more experience in writing learning process by peer assessment and students more interested and enjoy in joining learning activities.

Peers comments about students group task helped them to develop their written skill. Students were agreed that peer assessment technique can be rarely used in the teachinglearning process. This supported by Lew et al. (2008) in Alzaid (2017) about the students' response, he says that also noted in an exploratory study that students agree that peer assessment enables them to aid in the learning of their peers, that it was a fair way to evaluate them. And does not let personal relationships with peers influence their evaluations. Additionally, students understand the method of peer assessment as a learning expertise vital to the analysis process.

Furthermore, the researcher also found students' responses that student also agreed that there was a positive attitude when the teacher has implemented peer assessment in the classroom. The students more focus, critically and interest when they assessed, assessing, commenting their peer. It was appropriate with Lladó et al (2014) in Alzaid (2017) about the student response, he stated that students have a positive attitude toward peer-assessment methodology before and after its application. It stimulates student performance and facilitates the acquisition of learning at different levels.

Thus, they were agreed that peer assessment was effective technique used to helped students learn on writing. Interview responses show that many students helped to do a better presentation. Peers comments about the way students delivered the presentation helped them to develop their performance. Students were agreed that peer assessment technique can be rarely used in the teaching-learning process.

\section{CONCLUSION}

This research focused to investigate how the teacher implemented peer assessment in writing activity and to find out the students' responses toward peer assessment usage in a writing activity.

Based on the result of implementing peer assessment in writing activity using WhatsApp group chat, it can be concluded that peer assessment was a formative assessment as an alternative assessment to evaluate the teaching-learning process. The teacher also used peer assessment for designing learning environments on writing activity. The conclusion of this research as follows:

1. The implementation of peer assessment in writing activity

The implementation of peer assessment had four steps, namely; introduction, preparation, implementation or application and evaluation.

Students' can assess, be assessed, and give each other feedback for their work and made their judgements reasonably accurate in peer assessments. By using peer assessment in writing activity, students are expected to develop their ability in written some task using English. Training is considered to be the key factor in the success of peer assessment.

2. The student's responses toward the use of peer assessment 
The student's responses were positive. It can be seen from the attitude and enthusiasm. Students agreed that peer assessment is a very effective technique used in writing activities.

Students can make a good relationship between their peers by their group work, can be active participant and critical analyzer, students can have more experience in learning writing process by peer assessment and they are more interested in joining learning activities.

Peer assessment helps both students and teacher to carry out an assessment at their school especially on writing activity. It can be concluded that peer as sessment can be applied both in writing, speaking, and important part of the move towards more forms of participatory learning. There is a need to apply it in our schools and universities since it is more adaptable to modern developments in the assessment of learning outcomes.

\section{ACKNOWLEDGMENT}

The writer thanks to the headmaster, English teacher and the students of SMKN 1 Rawamerta who have participated in this research.

\section{REFERENCES}

Alzaid, Mohammed. (2017). The Effect of Peer Assessment on the Evaluation Process of Students. Canadian Center of Science and Education Publishers.

Boud, D., Cohen, R., \& Sampson, J. (2009). Peer learning and assessment. Assessment and Evaluation in Higher Education, 24(4), 413-426.

Brown, D. H. (2004). Language assessment: Principles and classroom practices. New York: Longman.

Chtravelu, Sithamparam and Choon. (2005). ELT Methodology, Principles and Practice.OxfordFajar. Malaysia.

Darma, S. D., Suwarno, B., \& Mulyadi, M. (2017). English Teachers' difficulties In Designing A Lesson Plan (Rpp) Based On Ktsp (A Study On English Teachers At Vocational High Schools In Bengkulu City. JOALL (Journal of Applied Linguistics \& Literature), 2(1), 7282.

Earl, S. E. (1986). Staff and peer assessment-Measuring an individual's contribution to group performance. Assessment and Evaluation in Higher Education, 11, 60-69.

Falchikov, N. (1994). Learning from peer feedback marking: Student and teacher perspectives. In H. C. Foot, C. J. Howe, A. Anderson, A. K. Tolmie, \& D. Warden (Eds.), Group and interactive learning (Vol. 1, pp. 411-416). Southampton, England: Computational Mechanics.

Faudi. (2016). The Implementation of Peer Assessment Technique in Teaching Writing. University of Syiah Kuala, Banda Aceh. 
Goh, C., \& Burns, A. (2012). Teaching Speaking: A holistic approach. Cambridge: Cambridge University Press.

Gupta. (2019). Peer Assessment in Writing: A Critical Review of Previous Studies. Journal of Advances in Linguistics 10 (2019): 1478-1487.

Hafernik, J. J. (1983, April). The how and why of peer editing in the ESL writing class.

Harris, John. 1993. Introducing Writing. London: Penguin English.

Iksan, M., \& Dirham, D. (2018). The Influence of the Economic Students' Motivations and Language Learning Strategies towards Their English Achievement in STIE Muhammadiyah Palopo. Ethical Lingua: Journal of Language Teaching and Literature, 5(1), 110-121. https://doi.org/10.30605/ethicallingua.v5i1.737

Kappe, F. (2008). How reliable is peer-assessment? Two empirical studies about assessment by students. Active Learning in Higher Education, 13(2), 129-142.

Kaso, N., Ilham, D., Aswar, N., \& Iksan, M. (2021). The Principal's Leadership: How to Improve the Quality of Teaching and Learning Process in State Junior High School of Luwu. In Jurnal Ad'ministrare (Vol. 8, http://ojs.unm.ac.id/index.php/administrare/index

Nelson, M. M., \& Schunn, C. D. (2009). The nature of feedback: How different types of peer feedback affect writing performance. Instructional Science, 37(4), 375-401.

Nunan, David. (2001). Second English Teaching and Learning. Beijing: Foreign Language Teaching and Research Press.

Okuda, R., \& Otsu, R. (2010). Peer assessment for speeches as an aid to teacher grading. The Language Teacher, 34(4), 41-47.

Stanciu, A., Mihai, F., \& Aleca, O. (2012). Social networking as an alternative environment for education. Accounting \& Management Information Systems/Contabilitate si Informatica de Gestiune, 11(1).

Sugiyono. (2012). Metode penelitian kualitatif dan R\&. Bandung: ALFABETA

Sugiyono. (2013). Metode penelitian Pendidikan (Pendekatan Kuantitatif \& Kualitatif). Bandung: Alfabeta.

Tarras, Maddalena. (2005). Assessment-Summative and Formative-Some Theoretical Reflections. University of Sunderland.Volume 53, No 4. http://pgce.soton.ac.uk/IT/Teaching/Assessment/Tarras.pdf. Accessed 22April 2019, 02: 30 p.m.

Topping, K. J., \& Ehly, S. (Eds.). (1998). Peer assisted learning. Mahwah, NJ: Erlbaum

Tsai, C.-C. (2009). Internet-based peer assessment in high school settings. In L. T. W. Hin \& R. Subramaniam (Eds.), Handbook of research on new media literacy at the K-12 level: Issues and challenges (pp. 743-754). Hershey, PA: Information Science Reference. 
White, E. (2009). Student perspectives of peer assessment for learning in a public speaking course. Asian EFL Journal - Professional Teaching Articles, 33(1), 1-36.

Iksan, M., \& Dirham, D. (2018). The Influence of the Economic Students' Motivations and Language Learning Strategies towards Their English Achievement in STIE Muhammadiyah Palopo. Ethical Lingua: Journal of Language Teaching and Literature, 5(1), 110-121. https://doi.org/10.30605/ethicallingua.v5i1.737

Kaso, N., Ilham, D., Aswar, N., \& Iksan, M. (2021). The Principal's Leadership: How to Improve the Quality of Teaching and Learning Process in State Junior High School of Luwu. In Jurnal Ad'ministrare (Vol. $\quad 8, \quad$ Issue 1 ). http://ojs.unm.ac.id/index.php/administrare/index

Wiraldi, Jufriadi, M. I. (2020). Improving Vocabulary Mastery Of The Seventh Year Students Using Scattergories Game In SMP Negeri 8 Palopo. FOSTER: Journal of English Language Teaching, 1(2), 159-167.

Yunella, Desha. (2016). Student Objectivity in Peer Assessment in an EFL Speaking Class. Banda Aceh. Syiah Kuala University.

Yu, S. \& Lee, I. (2016). Exploring Chinese Students' Strategy Use in a Cooperative Peer Feedback Writing Group. System, 58, 1-11.

Rubin, H.J. and Rubin, I.S. (2005) Qualitative Interviewing: The art of hearing data, 2nd edition, London: Sage Publications. 